\title{
PENGARUH FERMENTASI MENGGUNAKAN Trichoderma virideDAN Phanerochaete chrysosporium SERTA GABUNGAN KEDUANYA TERHADAP KOMPOSISI NUTRIEN TEPUNG JAGUNG SEBAGAI BAHAN BAKU PAKAN IKAN
}

\author{
Irma Melati, Mulyasari, dan Zafril Imran Azwar \\ Balai Penelitian dan Pengembangan Budidaya Air Tawar \\ Jl. Sempur No. 1, Bogor 16154 \\ E-mail: irma_melati08@yahoo.com
}

(Naskah diterima: 8 Desember 2011; Disetujui publikasi: 8 Maret 2012)

\begin{abstract}
ABSTRAK
Ketergantungan dunia akuakultur terhadap bungkil kedelai sangat besar. Dalam formulasi pakan ikan pemakaian bungkil kedelai bisa mencapai 30\% Padahal hampir sebagian besar bungkil kedelai masih mengandalkan impor sehingga harga pakan ikan mahal. Jagung berpotensi sebagai alternatif pengganti bungkil kedelai. Kendala yang dihadapi dalam pemanfaatannya sebagai bahan baku pakan adalah masih rendahnya nilai nutrien jagung dibandingkan bungkil kedelai. Tujuan penelitian ini adalah melihat pengaruh fermentasi menggunakan Trichoderma viride dan Phanerochaete chrysosporium serta gabungan keduanya (1:1) terhadap komposisi nutrien tepung jagung. Proses fermentasi dilakukan selama lima hari dengan dosis $10 \%(\mathrm{v} / \mathrm{b})$ dan diinkubasi pada suhu ruang $\left(30^{\circ} \mathrm{C}\right)$. Parameter yang diukur yaitu kadar nutrien tepung jagung meliputi kadar air, protein, lemak, abu serat kasar, dan BETN. Dari hasil penelitian menunjukkan bahwa fermentasi menggunakan $T$. viride, $P$. chrysosporium, dan gabungan keduanya sangat mempengaruhi nilai nutrien tepung jagung yaitu peningkatan kadar protein $(54,18 \% 131,45 \%)$; lemak $(25,18 \%$ 228,58\%); dan abu (1,61\% 2,31\%); serta penurunan bahan ekstrak tanpa nitrogen (BETN). Peningkatan protein paling tinggi diperoleh pada tepung jagung yang difermentasi menggunakan gabungan T. viride dan Phanerochaete chrysosporium yaitu sebesar $131,45 \%$ (dari $7,25 \%$ menjadi $16,78 \%$ ).
\end{abstract}

KATA KUNCl: fermentasi, tepung jagung, T. viride, $P$. chrysosporium

ABSTRACT: Effect of fermentation using Trichoderma viride and Phanerochaete chrysosporium and its combination to the nutrient composition of corn flour as raw material for fish feed. By: Irma Melati, Mulyasari, and Zafril Imran Azwar

Dependence of aquaculture on soybean meal is still high. The portion of soybean meal in fish feed formulation can reach $30 \%$ and unfortunately most of the soybean meal still depend on import. This problem become the reason why feed fish is very expensive. Corn is a potential raw material to substitute soybean meal in fish feed but cannot be utilized optimally because this stuff has very low nutrient value compared to soybean meal. The purpose of this research was to study the effect of fermentation using Trichoderma viride and Phanerochaete chrysosporium and its combination $(1: 1)$ to the nutrient composition of corn flour. The fermentation process was conducted at five days with dose of $10 \%(\mathrm{v} / \mathrm{w})$ and incubated at room temperature $\left(30^{\circ} \mathrm{C}\right)$. Parameters measured were water content, protein, fat, crude fiber, ash and nitrogen 
free exstract (NFE) content. The results showed that fermentation using $\boldsymbol{T}$. viride, $\boldsymbol{P}$. chrysosporium, and its combination greatly affect the nutrient value of corn flour. The fermentation could increased protein (54.18\%-131.45\%), fat (25.18\%-228.58\%), and ash (1.61\%-2.31\%) value but decreased NFE value. Combination of T. viride and $\boldsymbol{P}$. chrysosporium have the highest protein increased.

\section{KEYWORDS: fermentation, corn flour, T. viride, P. chrysosporium}

\section{PENDAHULUAN}

Ketergantungan dunia akuakultur terhadap bungkil kedelai sangat besar. Dalam formulasi pakan ikan pemakaian bungkil kedelai bisa mencapai 30\% Padahal hampir sebagian besar bungkil kedelai masih mengandalkan impor. Hal inilah salah satu menyebab harga pakan ikan menjadi sangat mahal. Indonesia merupakan negara agraris, di mana hasil- hasil pertanian sangat melimpah salah satunya jagung. Dilihat dari kelimpahannya potensi jagung sebagai alternatif pengsubstitusi bungkil kedelai cukup besar. Berdasarkan data sementara Badan Pusat Statistik 2010 total produksi jagung di Indonesia mencapai 18.364.430 ton dengan produsen utama adalah Provinsi Jawa Timur dengan total produksi 5.587.318 ton.

Kendala yang dihadapi dalam pemanfaatannya sebagai bahan baku pakan adalah masih rendahnya nilai nutrien jagung dibandingkan bungkil kedelai. Komposisi nutrien jagung sangat beragam tergantung pada tipe atau jenis jagung dan sangat dipengaruhi oleh faktor genetik dan lingkungan tumbuhnya. Menurut hasil analisis Laboratorium Kimia Nutrisi dan Teknlogi Pakan Ikan Balai Penelitian dan Pengembangan Budidaya Air Tawar Bogor, jagung mengandung protein kasar antara $7 \%$ $9 \%$ lemak kasar 2\% 4\% dan serat kasar 5\% 10\% Burge \& Duensing (1989) menyatakan bahwa kandungan serat kasar pada kulit ari jagung sangat tinggi yaitu sebesar $86,7 \%$ yang terdiri atas hemiselulosa $(67 \%)$, selulosa (23\%), dan lignin $(0,1 \%)$. Hal inilah yang menjadi faktor pembatas pemanfaatan jagung sebagai bahan baku pakan ikan. Diperlukan upaya untuk memperbaiki kualitas tepung jagung sehingga pemanfaatan dalam pakan menjadi optimal salah satunya dengan teknologi fermentasi.

Fermentasi merupakan suatu proses yang memanfaatkan mikroba untuk memperbaiki kualitas suatu bahan. Proses fermentasi relatif murah dan mudah dilakukan. Mikroba yang umum digunakan dalam fermentasi adalah
Trichoderma viride dan Phanerochaete chrysosporium. Trichoderma viride diketahui sebagai sumber enzim selulase komersial dan dapat menginduksi enzim yang berbeda sesuai dengan substrat yang digunakan (Fuller \& Aharon, 1987). Enzim lain yang dapat dihasilkan oleh Trichoderma viride antara lain protease, lipase, dan pektinase (Pelczar \& Reid, 1974; Wiseman, 1981; Rogers, 2002). Phanerochaete chrysosporium adalah golongan fungi yang dapat menghasilkan enzim cellebiosa dehydrogenase yang berfungsi untuk mendegradasi lignoselulosa (Monaco, 2001). Menurut Lynd et al. (2002), P. chrysosporium merupakan golongan fungi yang mempunyai enzim ektraseluler untuk mendegradasi selulosa (enzim selulase). Tujuan penelitian ini adalah melihat pengaruh fermentasi menggunakan Trichoderma viride dan $P$. chrysosporium serta gabungan keduanya (1:1) terhadap komposisi nutrien tepung jagung.

\section{BAHAN DAN METODE}

Tempat pelaksanaan penelitian ini yaitu Laboratorium Kimia Nutrisi dan Teknologi Pakan Ikan, Balai Penelitian dan Pengembangan Budidaya Air Tawar, Bogor. Kapang yang digunakan adalah Trichoderma viride, diperoleh dari Laboratorium Mikrobiologi, Pusat Antar Universitas (PAU) Institut Pertanian Bogor (IPB) dan P. chrysosporium yang diperoleh dari Laboratorium Mikrobiologi, Fakultas Matematika dan IImu pengetahuan Alam, Universitas Padjajaran (UNPAD).

\section{Fermentasi Tepung Jagung}

Ke dalam 6 wadah plastik masing- masing dimasukkan sebanyak $100 \mathrm{~g}$ tepung jagung dan ditambahkan air sebanyak $50 \%$ kemudian dikukus selama 30 menit. Setelah dikukus, didinginkan, kemudian diinokulasi dengan masing- masing larutan inokulum (T. viride, $P$. chrysosporium, dan gabungan keduanya (1:1)) sebanyak $10 \mathrm{~mL}$ untuk setiap wadah. Selanjutnya diinkubasikan selama 5 hari pada 
suhu ruang dan dalam kondisi aerob. Parameter yang diamati adalah kadar air dengan metode oven pada pemanasan $105^{\circ} \mathrm{C}$, kadar abu dengan metode tanur, protein kasar dengan metode kjedhal, lemak dengan metode ekstraksi langsung dengan soxhlet, dan serat kasar dengan metode ekstraksi asam- basa. Percobaan disusun menggunakan rancangan acak lengkap (RAL) dan masing- masing perlakuan terdiri atas tiga ulangan. Analisis data menggunakan software SPSS versi 11.

\section{HASIL DAN BAHASAN}

Berdasarkan hasil penelitian dapat dilihat bahwa terjadi kenaikan protein kasar yang cukup signifikan $(P<0,05)$ pada tepung jagung fermentasi dibandingkan tepung jagung tanpa fermentasi (Tabel 1).

Kenaikan protein tertinggi diperoleh pada jagung yang difermentasi oleh gabungan $T$. viride dan $P$. chrysosporium yaitu sebesar $130,19 \%$ (dari 7,29\% menjadi 16,78\%). Berdasarkan analisis statistik perlakuan ini berbeda nyata $(P<0,05)$ dengan perlakuan yang lain. Perbandingan kenaikan protein pada tepung jagung yang difermentasi oleh berbagai kapang bisa dilihat pada Gambar 1 .

Hasil penelitian ini sesuai dengan Suhenda et al. (2010) yang menggunakan $R$. oligosporus dan $A$. niger untuk fermentasi tepung jagung dengan dosis $9 \%(\mathrm{v} / \mathrm{b})$ dan waktu inkubasi 4 hari, memperlihatkan adanya peningkatan protein kasar masing-masing sebesar $86,30 \%$ (dari 9,49\%menjadi $17,68 \%$ ) dan 35,19\% (dari 9,49\% menjadi 12,83\%). Penelitian Mulyasari \& Melati (2011) menunjukkan adanya peningkatan protein kasar sebesar $112,5 \%$ (dari $7,29 \%$ menjadi $15,50 \%$ ) dan $72,18 \%$ (dari $7,29 \%$ menjadi $12,56 \%$ pada tepung jagung yang difermentasi dengan $R$. oligosporus dan $T$. reesei dengan dosis $10 \%(\mathrm{v} / \mathrm{b})$ dan waktu fermentasi 5 hari. Penelitian Ikhsan (1999) mencatat protein kasar ampas sagu aren yang difermentasi oleh Trichoderma viride dengan dosis $7 \%$ mengalami peningkatan sebesar $201,67 \%$ (dari 3,00\%menjadi 9,05\%).

Kenaikan protein pada proses fermentasi bisa disebabkan oleh pertumbuhan dan perkembangbiakan kapang. Wang et al. (1979) menyatakan peningkatan protein disebabkan oleh kenaikan jumlah massa sel kapang. Kapang merupakan sumber protein sel tunggal dengan kandungan protein sekitar 35\% 40\% (Fardiaz, 1987) sehingga pertumbuhannya (massa sel) memberikan sumbangsih yang cukup besar terhadap peningkatan protein pada produk fermentasi. Oboh \& Akindahunsi (2003) menyatakan bahwa kenaikan protein pada produk fermentasi disebabkan sekresi beberapa enzim ekstraselular (protein) seperti amilase, linamarase, dan selulase.

Kenaikan protein pada produk fermentasi selalu diikuti oleh penurunan karbohidrat (BETN + Serat kasar). Dari Tabel 1 dapat dilihat bahwa terjadi penurunan karbohidrat secara nyata di semua perlakuan. Penurunan tertinggi terjadi pada tepung jagung yang difermentasi oleh gabungan $T$. viride dan P. chrysosporium yaitu sebesar $20,90 \%$ (dari $89,39 \%$ menjadi $74,07 \%$. Perbandingan penurunan karbohidrat pada tepung jagung yang difermentasi oleh berbagai kapang dapat dilihat pada Gambar 2 .

Tabel 1. Komposisi nutrien tepung jagung fermentasi

Table 1. Nutrient composition of fermented corn flour (\% dry weight)

\begin{tabular}{|c|c|c|c|c|c|c|}
\hline \multirow{2}{*}{$\begin{array}{l}\text { Perlakuan } \\
\text { Treatments }\end{array}$} & \multirow{2}{*}{$\begin{array}{l}\text { Kadar air } \\
\text { Moisture }\end{array}$} & \multicolumn{5}{|c|}{$\begin{array}{l}\text { Bobot kering } \\
\text { Dry weight (\%) }\end{array}$} \\
\hline & & $\begin{array}{l}\text { Protein } \\
\text { Protein }\end{array}$ & $\begin{array}{l}\text { Lemak } \\
\text { Lipid }\end{array}$ & $\begin{array}{l}\text { Abu } \\
\text { Ash }\end{array}$ & $\begin{array}{l}\text { Serat kasar } \\
\text { Crude fiber }\end{array}$ & $\begin{array}{l}\text { BETN* } \\
\text { NFE }\end{array}$ \\
\hline Awal (initial) & $8.50^{\mathrm{a}}$ & $7.29^{a}$ & $2.08^{a}$ & $1.24^{\mathrm{a}}$ & $5.40^{\mathrm{a}}$ & $83.99^{a}$ \\
\hline T. viride & $59.16 \pm 1.99^{b}$ & $14.09 \pm 0.38^{b}$ & $2.84 \pm 0.44^{\mathrm{b}}$ & $2.05 \pm 0.07^{b}$ & $13.42 \pm 0.26^{b}$ & $67.60 \pm 0.32^{b}$ \\
\hline P. chrysosporium & $58.12 \pm 7.53^{b}$ & $11.18 \pm 0.44^{c}$ & $3.46 \pm 0.12^{c}$ & $1.62 \pm 0.24^{c}$ & $11.36 \pm 0.56^{c}$ & $72.39 \pm 0.70^{c}$ \\
\hline $\begin{array}{l}\text { T. viride } \& P \text {. } \\
\text { chrysosporium }\end{array}$ & $68.01 \pm 4.72^{\mathrm{b}}$ & $16.78 \pm 1.47^{d}$ & $6.83 \pm 0.32^{\mathrm{d}}$ & $2.31 \pm 0.24^{b}$ & $7.63 \pm 0.03^{d}$ & $66.44 \pm 1.98^{b}$ \\
\hline
\end{tabular}

* BETN: Bahan Ekstrak Tanpa Nitrogen 


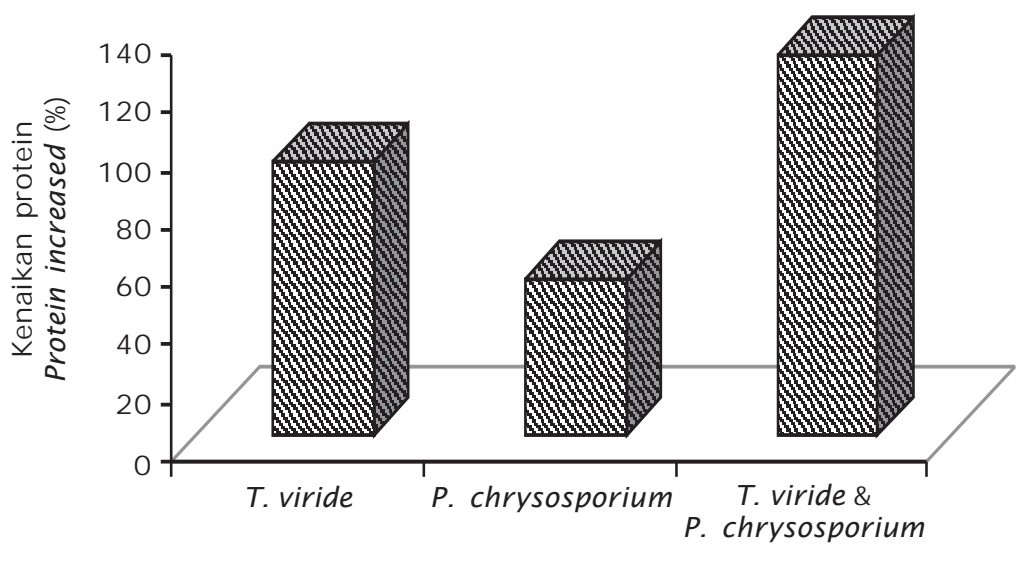

Jenis kapang (kind of fungi)

Gambar 1. Kenaikan protein (\%) tepung jagung fermentasi oleh berbagai macam kapang

Figure 1. Protein increased (\%) of fermented corn flour by various fungi

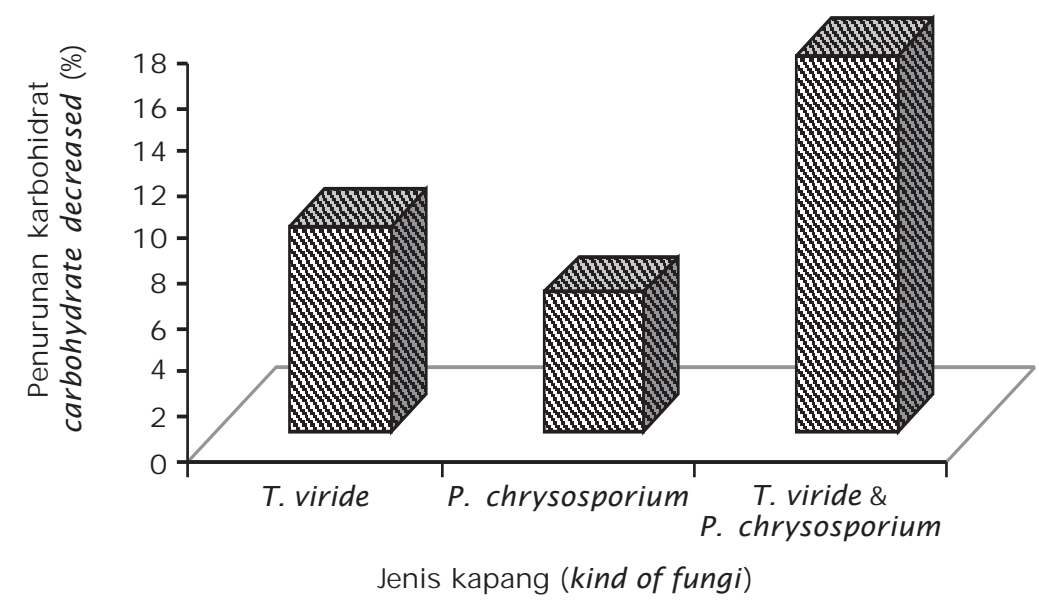

Gambar 2. Penurunan karbohidrat (\%) tepung jagung fermentasi oleh berbagai macam kapang

Figure 2. The carbohydrate decreased (\%) of fermented corn flour by various fungi

Hasil penelitian ini sesuai dengan penelitian Mulyasari \& Melati (2011) yang mencatat adanya penurunan karbohidrat sebesar $42,28 \%$ (dari $89,39 \%$ menjadi $51,60 \%$ ) dan 730,99\%(dari 89,39\%menjadi 61,89\%) pada tepung jagung yang difermentasi menggunakan $T$. reesei dan $R$. oligosporus dengan dosis $10 \%(\mathrm{v} / \mathrm{b})$ selama 5 hari. Penelitian Melati et al. (2011) menunjukkan adanya penurunan karbohidrat sebesar 7,27\%(dari 82,72\%menjadi $76,71 \%$ ) pada tepung kulit ubi kayu yang difermentasi dengan ragi tempe pada dosis $1 \%$ dan waktu inkubasi 7 hari. Penurunan karbohidrat terjadi karena kapang memanfaatkan karbohidrat sebagai sumber energinya. Hal ini sesuai dengan pernyataan Moore (2003) bahwa kapang menggunakan karbohidrat yang terdapat dalam bahan makanan sebagai sumber energi. Kapang merupakan mikroorganisme yang mampu menghidrolisis pati menjadi glukosa sebagai sumber karbon untuk pertumbuhannya (Oboh, 2005). 
Kandungan lemak tepung jagung hasil fermentasi dengan $T$. viride dan $P$. chrysosporium dan gabungan keduanya berkisar antara 2,84\%sampai 6,83\%(Tabel 1). Peningkatan lemak pada semua perlakuan berbeda nyata dibandingkan tepung jagung tanpa fermentasi. Peningkatan lemak paling tinggi diperoleh pada perlakuan gabungan $T$. viride dan $P$. chrysosporium yaitu sebesar $228,59 \%$ (dari 2,08\% menjadi 6,83\%). Hasil penelitian ini sedikit berbeda dengan hasil penelitian lain tentang fermentasi yang pada umumnya menurunkan kadar lemak pada produk fermentasi. Penelitian Azwar \& Melati (2010) memperlihatkan adanya penurunan lemak yang cukup tinggi pada tepung kulit ubi kayu yang difermentasi menggunakan $T$. viride dengan dosis 9\%dengan waktu fermentasi 7 hari yaitu sebesar $89,43 \%$ (dari 3,5\%menjadi $0,37 \%$ ). Hasil penelitian Melati et al. (2009) juga menunjukkan hal yang sama, di mana terjadi penurunan lemak pada ampas tahu yang difermentasi menggunakan $A$. niger dengan dosis $9 \%(\mathrm{v} / \mathrm{b})$ dan waktu fermentasi 7 hari yaitu sebesar $77,54 \%$ (dari 3,5\% menjadi $0,37 \%$ ). Perbandingan kenaikan lemak pada tepung jagung yang difermentasi oleh berbagai kapang dapat dilihat pada Gambar 3.

Peningkatan lemak pada tepung jagung hasil fermentasi diduga terjadi karena kapang dapat mengubah karbohidrat pada media/ subtrat menjadi lemak yang selanjutnya diakumulasikan sebagai lemak sel. Nuraida et al. (1996) menyatakan bahwa karbohidrat merupakan sumber $\mathrm{C}$ terbaik untuk pertumbuhan kapang dan sekitar 15\% 18\%gula yang tersedia dalam media akan diubah menjadi lemak. Kapang merupakan mikroorganisme yang secara efisien dapat mengubah glukosa menjadi lemak (Wassef, 1977). Rahman (1992) menyatakan bahwa untuk menginduksi akumulasi lemak dibutuhkan rasio $\mathrm{C} / \mathrm{N}$ yang tinggi sekitar 80:1. Jagung diduga merupakan bahan baku yang mempunyai $\mathrm{C} / \mathrm{N}$ rasio cukup tinggi mengingat kandungan pati pada jagung cukup tinggi sekitar $70 \%$ dari bobot biji, sedangkan proteinnya hanya berkisar antara $6,9 \%$ sampai $10 \%$ (\%K) sehingga dapat menginduksi akumulasi lemak pada sel kapang.

Fermentasi menggunakan $T$. viride dan $P$. chrysosporium dan gabungan keduanya menyebabkan kenaikan serat kasar pada tepung jagung yang berkisar antara $41,37 \%$ sampai dengan $148,51 \%$ Hasil analisis statistik menunjukkan bahwa semua perlakuan memberikan pengaruh yang berbeda nyata terhadap kenaikan serat kasar. Kenaikan serat kasar terendah terjadi pada perlakuan gabungan $T$. viride dan $P$. chrysosporium yaitu sebesar $41,37 \%$ (dari 5,40\%menjadi 7,63\%). Perbandingan peningkatan serat kasar pada jagung fermentasi dapat dilihat pada Gambar 4.

Peningkatan serat kasar pada proses fermentasi berasal dari dinding sel kapang sendiri. Menurut Gandjar et al. (2006), komponen penting dalam dinding sel sebagian

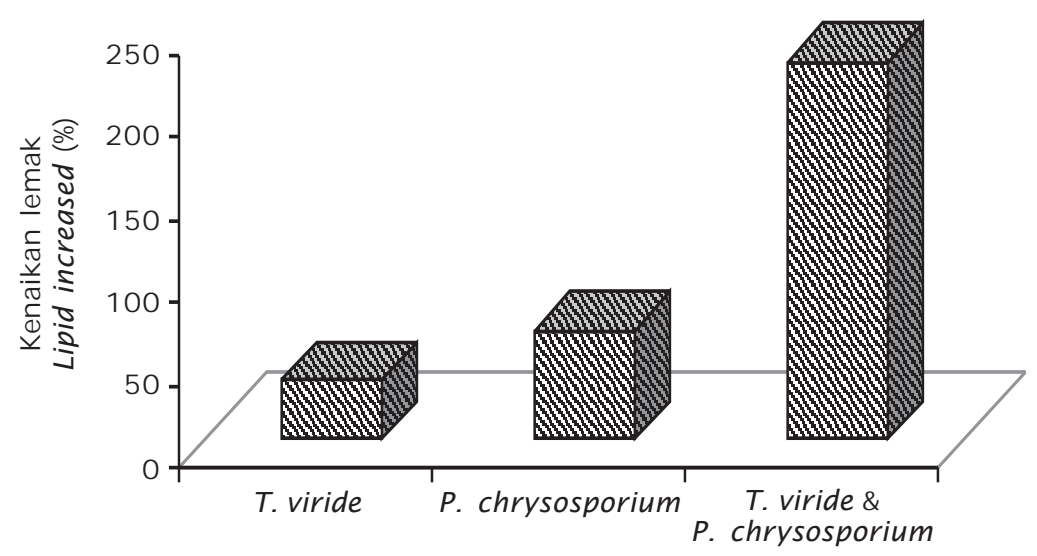

Jenis kapang (kind of fungi)

Gambar 3. Peningkatan lemak (\%) tepung jagung fermentasi oleh berbagai macam kapang

Figure 3. Lipid increased (\%) of fermented corn flour by various fungi 


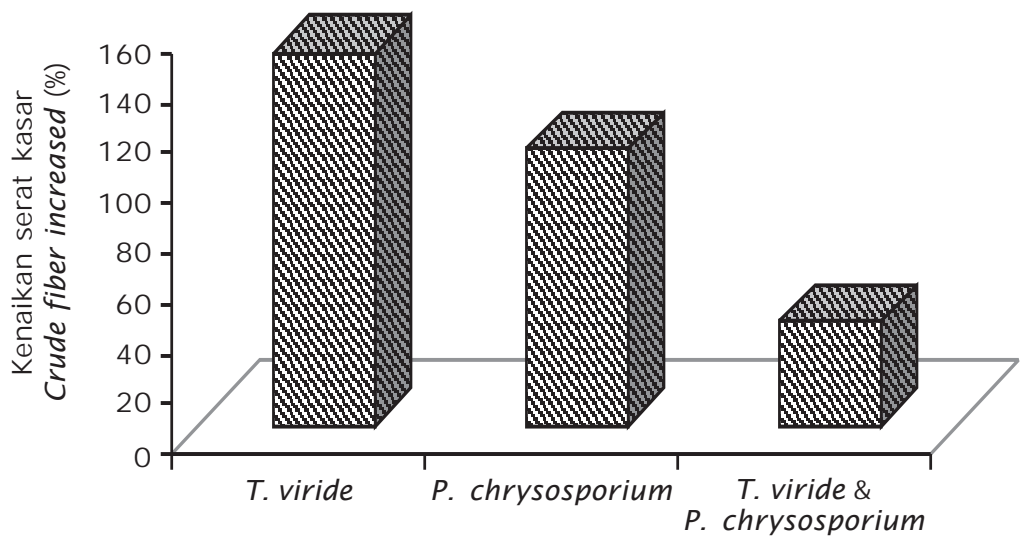

Jenis kapang (kind of fungi)

Gambar 4. Peningkatan serat kasar (\%) tepung jagung fermentasi oleh berbagai macam kapang

Figure 4. Crude fiber increased (\%) of fermented corn flour by various fungi

besar fungi adalah kitin. Kitin merupakan polisakarida yang juga merupakan komponen utama dari kerangka luar serangga atau antropoda.

\section{KESIMPULAN}

Hasil penelitian menunjukkan bahwa fermentasi menggunakan $T$. viride, $P$. chrysosporium, dan gabungan keduanya, sangat mempengaruhi komposisi nutrien tepung jagung yaitu terjadinya peningkatan kadar protein $(54,18 \% 131,45 \%)$; lemak (25,18\% 228,58\%); dan abu (1,61\% 2,31\%); serta penurunan bahan ekstrak tanpa nitrogen (BETN). Peningkatan protein paling tinggi terjadi pada tepung jagung yang difermentasi menggunakan gabungan $T$. viride dan $P$. chrysosporium yaitu sebesar $131,45 \%$ (dari 7,25\%menjadi 16,78\%.

\section{DAFTAR ACUAN}

Azwar, Z.I. \& Melati, I. 2010. Perbaikan kualitas tepung kulit ubi kayu melalui fermentasi menggunakan Trichoderma viride. Prosiding Simposium Nasional Bioteknologi Akuakultur III. Fakultas Perikanan dan IImu Kelautan, Institut Pertanian Bogor, hlm. 6472.

Badan Pusat Statistik (BPS). 2010. Luas Panen Produktivitas Produksi Jagung Seluruh Provinsi, 2010. http:// www.bps.go.id. Diakses tanggal 8 Juni 2011.
Burge, R.M. \& Duensing, W.J. 1989. Processing and dietary fiber ingredient application of combran. Cereal Foods World, 34: 535- 538.

Fardiaz, S. 1987. Fisiologi fermentasi. PAU IPB dengan LSI IPB Bogor, hIm. 171.

Fuller, M.P. \&Aharon, G. 1987. Microorganism as digestors of seaweed cell walls. Hydrobiologia, 151/ 152: 405- 409.

Gandjar, I., Syamsuridzal, W., \& Oetari, A. 2006. Mikologi: Dasar dan Terapan. Yayasan Obor Indonesia. Jakarta, $238 \mathrm{hlm}$.

Ikhsan, I. 1999. Pengaruh level inokulum Tricoderma viridie dan lama fermentasi terhadap kandungan protein kasar ampas sagu aren. Skripsi. Fakultas Peternakan UNAND, Padang, $12 \mathrm{hlm}$.

Lynd, L.R., Weiner, P.J., Van Zyl, W.H., \& Pretorius, I.S. 2002. Microbial cellulose utilization: Fundamental and nutrientlogy. Microbial. Mol. Biol. Rev., 66: 506- 577.

Melati, I., Azwar, Z.I., \& Saputra, A. 2011. Pemanfaatan ragi tempe untuk perbaikan kualitas tepung kulit ubi kayu sebagai bahan baku pakan ikan. Prosiding Seminar Nasional Tahunan VIII Hasil Penelitian Perikanan dan Kelautan, UGM, hlm. 604-611.

Melati, I., Azwar, Z.I., \& Kurniasih, T. 2009. Pemanfaatan ampas tahu terfermentasi sebagai susbtitusi tepung kedelai dalam formulasi ikan patin. Prosiding Forum Inovasi Teknologi Akuakultur. Pusat Riset Perikanan Budidaya, hlm. 713- 719. 
Monaco, S. 2001. Cellubiosa dehydrogenase. http/ / Ftp.esrp.eu/pub/user reports/ 18802_F.FDF. Diakses tanggal 21 Juni 2011.

Moore, E. 2003. Fundamentals of Fungi. Prentice- Hall inc. New York University, 22 pp.

Mulyasari \& Melati, I. 2011. Perbandingan nutrien tepung jagung hasil fermentasi menggunakan Tricoderma reesei dan Rhizopus oligosporus sebagai bahan baku pakan ikan. Prosiding Seminar Nasional Tahunan VIII Hasil Penelitian Perikanan dan Kelautan, UGM, hlm. 559- 603.

Nuraida, L., Niehaber, N.L.P., Winarno, Swandoko, G.A., \& Rahman, A. 1996. Pengaruh kondisi fermentasi terhadap produksi minyak kapang Mucor inaequisporus M 05II/4. Bul. Tek. dan Industri Pangan, VII(I): 79-86.

Oboh, G. 2005. Nutrient enrichment of cassava peels using a mixed culture of Saccharomyces cerevisae and Lactobacillus spp. solid media fermentation techniques. Electronic J. of Biotechnology [online]. 9(1) [cited 6 May 2011]. Available from: http:// www. ejbiotechnology.info/ content/ vol1/ issue3/ full/ 9/ 9.PDF. ISSN 0717- 3458.

Oboh, G. \&Akindahunsi, A.A. 2003. Biochemical changes in cassava products (flour \& gari) subjected to Saccharomyces cerevisae solid media fermentation. Food Chemistry, 82(4): 599-602.

Pelczar, M.J. \& Reid, R.D. 1974. Microbiology. McGraw Hill Book Co., New York, 948 pp.

Rahman, A. 1992. Teknologi fermentasi industrial II. Arcan. Jakarta, 186 hlm.

Rogers, J.M. 2002. Diamond V xp ${ }^{\mathrm{TM}}$ DFM sets the standard in microbial feed technology. http:/ / www.Diamond.com/ newsrelease/ xp_dfm_aug 2000.htmL.

Suhenda, N., Melati, I., \& Samsudin, R. 2010. Peningkatan mutu tepung jagung melalui proses fermentasi dengan menggunakan tiga jenis kapang berbeda sebagai bahan baku pakan ikan mas (Cyprinus carpio). Prosiding Seminar Nasional Tahunan VII Hasil Perikanan dan Kelautan. Universitas Gajah Mada (UGM), 20: 1- 5.

Wang, D.I.C, Cooney, C.I., \&Demein, A.L. 1979. Fermentation and Enzymes Technology. John and Sons Inc., p. 468- 472.

Wassef, M.K. 1977. Fungal Lipids. In. Paoletti, A. \& Kritchersky, D. (Eds.). Advanced in Lipid Research. Academic Press. New York, p. 159- 230.

Wiseman, A. 1981. Topics in enzyme fermentation biotechnology. Jhon Willey and Sons, New York, 359 pp. 